\title{
АНАЛІЗ ВПЛИВУ ЗАХОДІВ НЕТАРИФНОГО РЕГУЛЮВАННЯ НА ПОКАЗНИКИ МІЖНАРОДНОї ТОРГІВЛІ: МЕТОДИЧНИЙ АСПЕКТ
}

\section{ANALYSIS OF THE IMPACT OF NON-TARIFF REGULATION MEASURES ON INTERNATIONAL TRADE INDICATORS: METHODICAL ASPECT}

\author{
Довгаль Олена Андріївна \\ доктор економічних наук, профресор, \\ Харківський національний університет імені В.Н. Каразіна \\ ORCID: https://orcid.org/0000-0003-3219-9731 \\ Довгаль Георгій Володимирович \\ кандидат економічних наук, доцент, \\ Харківський національний університет імені В.Н. Каразіна \\ ORCID: https://orcid.org/0000-0002-0644-1793 \\ Коваленко Роман Сергійович \\ кандидат економічних наук, доцент, \\ Харківський національний університет імені В.Н. Каразіна \\ ORCID: https://orcid.org/0000-0001-6676-1767 \\ Dovgal Olena, Dovgal Georgiy, Kovalenko Roman \\ V.N. Karazin Kharkiv National University
}

\begin{abstract}
Стаття присвячена актуальним питанням використання нетарифнних заходів у сучасній міжнародній торгівлі, які суттєво ускладнюють переміщення товарів і послуг між країнами, знижуючи ефективність взаємовигідного міжнародного економічного співробітництва, перешкоджаючи розвитку й кооперації технологічних галузей. Розглянуто особливості, переваги та недоліки основних методичних підходів до оцінки впливу заходів нетарифного регулювання на показники міжнародної торгівлі: метод частотного аналізу, метод оцінки різниці цін і пов'язаний з ним метод оцінки тарифрного еквіваленту, метод розрахунку змін цін внаслідок кількісних змін обсягу імпорту, методи індексного аналізу та економетричних оцінок. Зроблено висновок, що характерні для кожного з розглянутих методів переваги й недоліки обумовлюють необхідність вибору відповідної методики в залежності від цілей дослідження і наявних даних.
\end{abstract}

Ключові слова: міжнародна торгівля, нетарифні заходи, тарифні заходи, регулювання зовнішньої торгівлі.

Статья посвящена актуальным вопросам использования нетарифных мер в современной международной торговле, которые существенно затрудняют перемещение товаров и услуг между странами, снижая эфрфрективность взаимовыгодного международного экономического сотрудничества, препятствуя развитию и кооперации технологических отраслей. Рассмотрены особенности, преимущества и недостатки основных методических подходов к оценке влияния мер нетариорного регулирования на показатели международной торговлы: метод частотного анализа, метод оценки разницы цен и связанный с ним метод оценки тарифного эквивалента, метод расчета изменений цен вследствие количественных изменений объема импорта, методы индексного анализа и эконометрических оценок. Сделан вывод, что характерные для каждого из рассмотренных методов преимущества и недостатки обусловливают необходимость выбора соответствующей методики в зависимости от целей исследования и имеющихся данных.

Ключевые слова: международная торговля, нетарифные меры, тарифные меры, регулирование внешней торговли.

The article is devoted to topical issues of the use of non-tariff measures in modern international trade, which significantly impede the movement of goods and services between countries, reducing the effectiveness of mutually beneficial international economic cooperation, hindering the development and cooperation of technological indus- 
tries. The benefits of participants in international economic relations from the elimination of obstacles to mutual trade are confirmed by many years of international experience. The features, advantages and disadvantages of the main methodological approaches to assessing the impact of non-tariff regulation measures on international trade indicators are considered: the method of frequency analysis, the method for assessing the price difference and the associated method for assessing the tariff equivalent, the method for calculating price changes due to quantitative changes in the volume of imports, methods of index analysis and econometric estimates. It is proved that research on the impact of non-tariff barriers focuses on determining such indicators of international trade as the share of imports (in value or number of commodity items), for which non-tariff regulation measures are applied; tariff equivalents of non-tariff measures; change in the volume of exports or imports under the influence of non-tariff measures; change in terms of trade under the influence of non-tariff measures, etc. It was found that all these methods have both strengths and weaknesses related to data availability, calculation and evaluation mechanisms, reliability and relevance of the results. It is substantiated that the main methodological approaches to assessing the impact of non-tariff measures on the indicators of international trade that have been analyzed, provide to some extent an assessment of the level and intensity of these measures for exporters. It is concluded that the advantages and disadvantages characteristic of each of the considered methods necessitate the choice of an appropriate technique, depending on the objectives of the study and the available data.

Keywords: international trade, non-tariff measures, tariff measures, regulation of foreign trade.

Постановка проблеми. Використання нетарифних заходів у сучасній міжнародній торгівлі суттєво ускладнює переміщення товарів і послуг між країнами, знижуючи есрективність взаємовигідного міжнародного економічного співробітництва, перешкоджаючи розвитку й кооперації технологічних галузей. Вигода учасників міжнародних економічних відносин від усунення перешкод у взаємній торгівлі підтверджується багаторічним міжнародним досвідом. Наприклад, згідно з результатами дослідження Генерального директорату 3 економічних та фрінансових справ Європейської Комісії, проведеного у 2018 році, вигоди від фрормування внутрішнього ринку без бар'єрів оцінювалися сукупно у 6-6,5\% від валового внутрішнього продукту (ВВП) держав-членів ЄС [25].

Суттєве розширення масштабів використання і значущості заходів нетарисрного регулювання зовнішньої торгівлі, що спостерігається з кінця XX століття, підвищило актуальність дослідження економічних наслідків впровадження нетарифрних бар'єрів у процесі організації державної зовнішньоторговельної політики [20; 26]. Це відноситься і до задачі оцінки їх впливу на торговельні потоки, що $€$ в ряді аспектів навіть більш складнішою, ніж у випадку з тарифнними бар'єрами. По-перше, відповідно до найбільш повної і широко використовуваної класифрікації заходів нетарифного регулювання, що була розроблена з ініціативи Конференції ООН з торгівлі і розвитку (ЮНКТАД), наразі налічується близько 180 видів нетарифних заходів зовнішньоторговельного регулювання [27, р. 186], кожен з яких здатний виступати в ролі бар'єру. По-друге, на відміну від тарифнних інструментів, дія нетарифнних заходів не обмежується митним кордоном, а поширюється на весь внутрішній ринок держави, яка їх застосовує. По-третє, вплив одних і тих же нетарифнни заходів може по-різному позначатися на експортерів внаслідок того, що їх виконання вимагає від них різного об'єму ресурсів [13]. Нарешті, по-четверте, багато нетарифних заходів не мають кількісного вираження, що ускладнює їх аналіз у принципі. Ідентифрікувати й оцінити в цих умовах характер дії кожного окремого нетарифного заходу буває вкрай складно.

Аналіз останніх досліджень і публікацій. Методичним питанням, включаючи питання визначення та класифрікації нетарифрних заходів, присвячені роботи Р. Болдуина [2], А. Дирдорфра та Р. Штерна [10], С. Басу, Г. Кувахара та Ф. Думешила [4], Р. Стайгера [24], Дж. Бхагваті та Т. Срінівасана [7], Б. Хокмана та А. Ніцита [14]. Взагалі у сучасній науковій літературі розроблено багато окремих підходів до оцінки впливу нетарифних заходів на міжнародну торгівлю, однак, майже відсутній узагальнений аналіз їх переваг та недоліків.

Саме тому метою роботи $є$ узагальнення особливостей, переваг та недоліків існуючих методичних підходів до оцінки впливу нетарифрних заходів на показники міжнародної торгівлі.

Виклад основного матеріалу. Якправило, дослідження впливу нетарифних бар'єрів фокусуються на визначенні таких показників міжнародної торгівлі: частка імпорту (у вартісному обсязі або кількості товарних позицій), щодо якої застосовуються заходи нетарифного регулювання [1; 21]; тарифні еквіваленти нетарифрних заходів [9]; зміна обсягу експорту або імпорту під впливом нетарифрних заходів [8]; зміна умов торгівлі під впливом нетарифрних заходів [5; 15] тощо. 
Найбільш часто для оцінки впливу нетарифнних заходів використовуються метод частотного аналізу, метод оцінки різниці цін і пов'язаний 3 ним метод оцінки тарифного еквіваленту, метод розрахунку змін цін внаслідок кількісних змін обсягу імпорту, методи індексного аналізу та економетричних оцінок.

Одним 3 перших використовуваних підходів став метод частотного аналізу (frequencytype measures), заснований на оцінці поширеності заходів нетарифрного регулювання зовнішньої торгівлі. Спроби оцінки нетарифрних заходів за допомогою частотного підходу були зроблені на початку 1980-х рр. [1; 11]. Однак основною на базі даного підходу стала спільна робота Світового банку і ЮНКТАД 3 оцінки впливу нетарифних заходів, що діяли на кордонах 16 промислово-розвинених країн у 1981-1984 рр. [21; 22].

В даному дослідженні було розраховано три види показників за формулою:

$$
I=\frac{\sum q \in Q \sum x \in X W q x N q x}{\sum q \in Q \sum x \in X W q x}
$$

де $q$ - товарна позиція із загальної кількості товарів, що імпортуються $Q$;

$x$ - країна-постачальник товару $q$ загальної кількості $X$ країн-експортерів;

$W q x$ - показник імпорту товара q, що визначається трьома шляхами для трьох різних показників: 1) для показника застосування нетарифнних заходів певною країною-імпортером (Ic) Wqx - обсяг імпорту товару $q$ з країни $x$; 2) для показника використання нетарифрних заходів щодо певної категорії товарів $q$ у світовій торгівлі в цілому (Ic) Wqx - обсяг світового імпорту товару $q$; 3) для показника частоти застосування нетарифних заходів (Ic) $W q x-$ змінна наявності $(W q x=1)$ або відсутності $(W q x=0)$ імпорту товару $q$ з країни $x$;

$N q x$ - бінарна змінна застосування $(N q x=1)$ або відсутності $(N q x=0)$ нетарифрних заходів щодо імпорту товару $q$ з країни $x$.

Розрахунки показали, що у середньому заходи нетарифного регулювання зовнішньої торгівлі застосовувалися щодо 13\% товарних позицій, які орормували $27 \%$ обсягу імпорту. При цьому найбільш схильними до нетариснних заходів були текстильні товари, сільськогосподарська сировина і продукти харчування, а також паливні товари: за їх допомогою регулювалося близько 45\%, 36\% і 43\% імпорту зазначених категорій товарів відповідно (табл. 1).

Даний підхід було також використано СОТ у 2012 р. при оцінці динаміки використання нетарифрних заходів у світовій торгівлі. Результати дослідження показали, що в період 2001-2010 рр. більше половини вартісного обсягу світового імпорту регулювалося саме за їх використанням (рис. 1).

Головним недоліком цього методу виступає те, що показники, які розраховуються на його основі, характеризують лише наявність і поширення нетарифних заходів серед окремих категорій товарів, однак відсутня можливість оцінки ступеня їх впливу. Більш того, при використанні частотного підходу можливі різні спотворення. Наприклад, чим більше обмежувальний вплив конкретного нетарифного заходу, тим менше може виявитися ії вага в індексі через зниження обсягу імпорту відповідного товару аж до того, що відображення

Частка використання нетарифних заходів розвиненими країнами за окремими категоріями товарів у 1983 р., \%

\begin{tabular}{|c|c|c|c|}
\hline Категорії товарів & Власний імпорт (Ic) & Світова торгівля (Iw) & Частота (If) \\
\hline Всі товари & 27,1 & 21,8 & 12,8 \\
\hline Всі товари, крім паливних & 18,6 & 18,5 & 12,7 \\
\hline Паливні товари & 43,0 & 31,0 & 23,9 \\
\hline $\begin{array}{l}\text { Сільськогосподарська сировина } \\
\text { і продукти харчування }\end{array}$ & 36,1 & 40,4 & 29,5 \\
\hline Промислові товари & 16,1 & 14,9 & 10,8 \\
\hline $\begin{array}{l}\text { У тому числі: } \\
\text { текстильні вироби }\end{array}$ & 44,8 & 37,8 & 38,1 \\
\hline Взуття & 12,6 & 17,7 & 13,5 \\
\hline метали і вироби з них & 35,4 & 35,8 & 18,3 \\
\hline електрообладнання & 10,0 & 10,8 & 5,4 \\
\hline транспортні засоби & 30,4 & 25,9 & 7,4 \\
\hline інші товари & 8,8 & 7,2 & 3,2 \\
\hline
\end{tabular}

Таблиця 1 


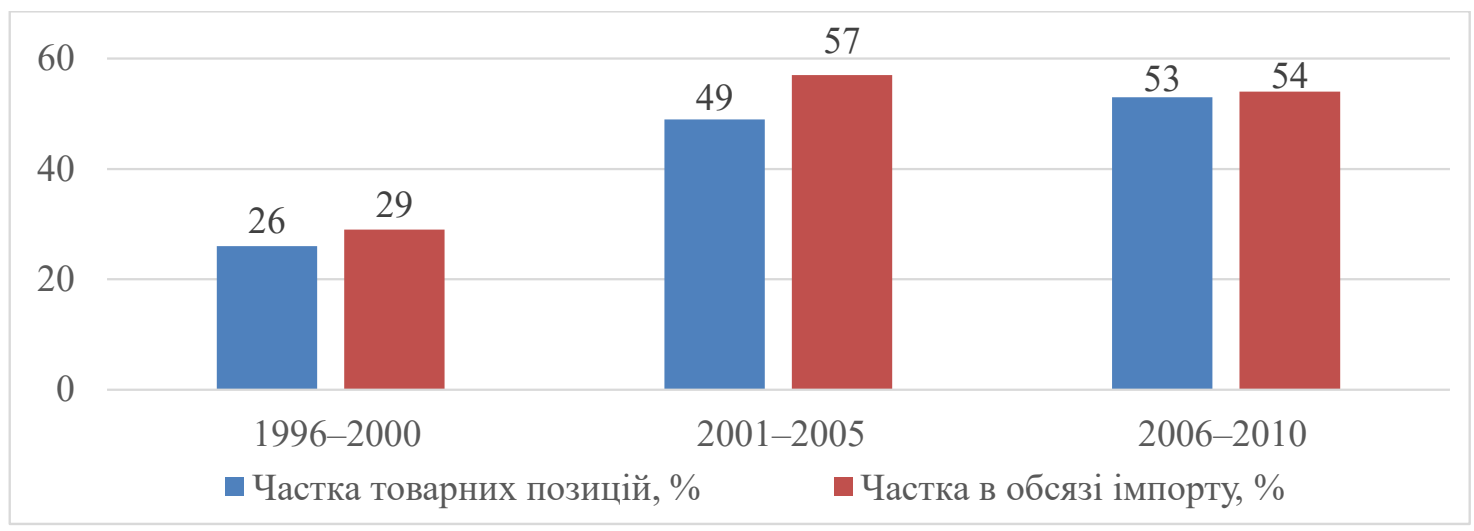

Рис. 1. Частка товарних позицій та обсягу імпорту у світовій торгівлі, щодо яких застосовувалися міри нетарифного регулювання у 1996-2010 рр., \%

Джерело: [28]

цього заходу в отриманому індексі виявиться нульовим. Крім того, труднощі виникають і в міжчасових порівняннях через зміни обсягів і структури імпорту.

3 цієї причини, наприклад Дж. Ногуес, А. Олечовскі і Л. Вінтерс, розраховували поширеність заходів нетарифнного регулювання, використовуючи в якості ваг показники імпорту одного і того ж періоду, що дозволило оцінити динаміку поширеності їх використання, проте не їх обмежувальний вплив [20].

Більш ефективним у вирішенні цього завдання вважається метод різниці цін (price gap), орієнтований на оцінку зміни цін саме під впливом заходів нетарифнного регулювання [8]. У цьому випадку стає можливим розрахунок відсоткового тарифного еквіваленту нетарифнних заходів (за аналогією із тарифними інструментами), що характеризує зміну ціни імпортованого товару під їх впливом. Логіка зазначеного підходу заснована на порівнянні ціни імпортованого товару на внутрішньому ринку, що формується з урахуванням заходів нетарифнного регулювання, $з$ ціною зарубіжного постачальника, вплив нетарифрних заходів на яку поки що відсутній:

$$
T e=\frac{P b-P X}{P X},
$$

де $\mathrm{Pb}$ - ціна імпортованого товару на внутрішньому ринку (з урахуванням нетарифних заходів);

$P X$ - ціна імпортованого товару (з урахуванням транспортних витрат і тарисрів, але без урахування нетарисрних заходів);

Te - тарифрний еквівалент нетарисрних заходів.

Цей метод також має ряд недоліків. Перший з них пов'язаний з даними щодо цін. Якщо ціни внутрішнього ринку доступні для вимірювання, то доступ до даних щодо цін зарубіжних експортерів $є$ обмеженим. Ще однапроблемапов'язана з вибором цін й урахуванням інших фракторів, що впливають на ціни (коливання валютних курсів, оптові та роздрібні націнки тощо). I третій, більш значущий недолік пов'язаний з відмінностями між самими заходами нетарифного регулювання та характером їх дії: нетарифнні заходи впливають на ціну товару на різних стадіях виробництва і поставки, що ускладнює порівняння тариснного еквівалента різних заходів нетарифрного регулювання.

М. Ферантино [12] запропонував оцінювання впливу різних заходів нетарифного регулювання на кожній стадії поставки товару від виробництва до кінцевого споживача в країні-імпортері, однак такий підхід $є$ важким, так як вимагає надійних цінових даних на кожній стадії поставки.

В ряді досліджень $[17 ; 18]$ застосовувався метод розрахунку змін цін внаслідок кількісних змін обсягу імпорту під дією нетарифнних заходів. Для його використання необхідно оцінити еластичність попиту й пропозиції на імпортний і місцевий товари. Безумовно, в цьому випадку багато залежить від характеру і структури ринку певного товару. А тому, якщо імпортний товар не має місцевих товарів-замінників, необхідно розрахувати еластичність попиту і пропозиції тільки імпортного товару. Якщо ж імпортний і місцевий товари взаємозамінні, потрібно розрахувати еластичність попиту і пропозиції місцевого товару, а також еластичність цін імпортного та місцевого товарів. Ще одним фрактором виступає конкуренція, яка визначає мінливість еластичності попиту і пропозиції. 
Так, А. Мороз та С. Браун [19] розраховували ефрект заходів нетарифного регулювання у сфрері державних закупівель Канади за фрормулою:

$$
T e=\frac{\Delta Q}{Q m} \times \frac{1+t}{L},
$$

де $\Delta Q m$ - зміна обсягу імпорту після введення нетариорних заходів;

Qm - обсяг імпорту до введення нетарифрних заходів;

$t$ - рівень імпортного тарифу;

$L$ - еластичність попиту на внутрішньому ринку на імпортний товар.

Ключовим завданням для ефективного використання даного методу виступає оцінка коефіцієнтів еластичності, що вимагає значних ресурсів.

Метод індексного аналізу базується на розрахунку індексів впливу заходів нетарифного регулювання на торгівлю на основі даних, отриманих при опитуваннях компаній. Так, у ході опитування 3518 компаній США і країн $€ С$ оцінювали вплив заходів нетарифного регулювання за шкалою від 0 (відсутність впливу) до 100 (заборонний характер нетарифрних заходів). На основі отриманих бальних оцінок для кожної з 14 товарних груп, а також 39 видів послуг було розраховано індекс нетарисних заходів, що характеризує середній рівень їх обмежувального впливу на експорт з країн ЄС до США і з США - до країн $€ C$ [9]. Цей метод може вважатися методом прямої оцінки впливу нетарифрних заходів на ціни або кількість товарів, що імпортуються.

Альтернативою йому виступає підхід, заснований на оцінці цінових і кількісних ефректів нетарифнних заходів за допомогою регресійного аналізу, перш за все гравітаційних моделей і моделей попиту на імпорт. 3 моменту розробки у 1960-х рр. гравітаційна модель стала широко застосовуватися для аналізу торгових потоків [3; 23]. Основними її перевагами є значна стійкість й висока пояснювальна здатність [6]. Саме ці властивості стандартних змінних гравітаційної моделі забезпечили її популярність при аналізі ефректів різних чинників міжнародної торгівлі, включаючи нетарифнні заходи [16].

При цьому необхідно відзначити і недоліки гравітаційної моделі. По-перше, ендогенність моделі (залежна змінна - експорт) враховується при розрахунку однієї з пояснювальних змінних - ВВП. По-друге, стійкість моделі, яка пояснюється фракторами ВВП, відстаней, а також наявності спільних кордонів, ускладнює відстеження есректів інших фракторів моделі.
У дослідженнях нетарифних заходів, що проводяться на основі гравітаційних моделей, специфрікація моделі у загальному вигляді має наступний вигляд [28]:

$\ln M_{i j}{ }^{k}=a+b_{1} \ln \left(1+T_{i j}{ }^{k}\right)+b_{2} N T M_{i j}{ }^{k}+\sum C n X_{i j}{ }^{k}$,

де $M_{i j}{ }^{k}$ - обсяг імпорту до країни $i$ з країни $j$ товару $k$;

$T_{i j}{ }^{k}-$ рівень тарифру на імпорт до країни $i$ з країни $j$ товару $k$;

$N T M_{i j}{ }^{k}$ - фріктивна змінна застосування нетарифнни заходів у країні $i$ щодо товару $k$, що імпортується з країни $j$;

$X_{i j}{ }^{k}$ - вектор змінних гравітаційної моделі включає показники, що характеризують розмір економік або ринків країн-партнерів $i$ та $j$ (обсяг ВВП або обсяг ВВП на душу населення, рівень доходу, чисельність населення тощо), а також показники, що характеризують умови торгівлі (відстань між країнами, а також інші показники в залежності від завдань дослідження).

Дана специфікація дозволяє розраховувати обсяги імпорту як при наявності, так і при відсутності заходів нетарифного регулювання. В цьому випадку ефект дії нетарифнних заходів буде виражений у різниці цих значень. Ecorys для розрахунку ефекту заходів нетарифного регулювання в торгівлі країн НАФТА і країн $€ С$ використовувала гравітаційну модель для безпосереднього розрахунку тарифного еквіваленту нетарифнних заходів [9]. При цьому модель враховувала наявність або відсутність спільного сухопутного кордону, мови і розташування на одному континенті:

$$
\ln t_{i j}=\ln \left(1+T_{i j}{ }^{k}\right)+y \ln N_{i j}+\delta \ln D i s t_{i j}+\zeta d u m A d j_{i j}+
$$$$
+ \text { ndumCont }_{i j}++ \text { - } \text { dumLang }_{i j}+e_{i j} \text {, }
$$

де $t_{i j}$ - тарифрний еквівалент нетарисрних заходів, що використовуються;

$T_{i j}{ }^{k}$ - рівень тарифру на імпорт товару $k 3$ країни $i$ до країни $j$;

$N_{i j}$ - середній індекс нетарифнних заходів країни $j$ щодо країни $i$;

Dist ${ }_{i j}$ - відстань між країнами $j$ та $i$;

dumAdjij - фріктивна змінна загального кордону між країнами $j$ та $i$;

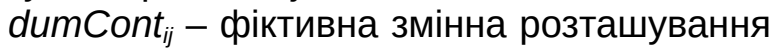
країн $j$ та $i$ на одному континенті;

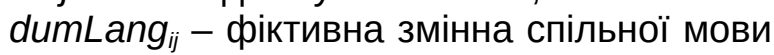
країн $j$ та $i$;

$e_{i j}$ - залишки регресії.

Розрахунки Ecorys довели, що наявність нетарифного заходів підвищує ціну експортованих з США до $Є С$ продуктів харчування на $56,8 \%$, косметичних товарів - на 34,6\%, хімічних товарів - на 23,9\%, металів - на 11,9\% [8]. 
У 2018 р. С. Берні і Дж. Райс використовували наступну специфрікацію гравітаційної моделі для розрахунку ефектів дії нетарифрних бар'єрів у торгівлі Ірландії з Великою Британією після виходу останньої з ЄС:

$$
\begin{gathered}
\ln \left(I m p_{i j k} / I m p_{i h k}\right)=\alpha+\beta \ln \left(G D P_{j} / G D P_{h}\right)+ \\
\quad+y \ln \left(D t_{j k} / D t_{h k}\right)++\lambda \ln \left(T_{j} / T_{k}\right)+ \\
+\eta \ln \left(X R_{j} / X R_{k}\right)+\varphi\left(D_{j k}-D_{h k}\right)+\varepsilon_{i j h k},
\end{gathered}
$$

де $I m p_{i j k}$ и $I m p_{i h k}-$ імпорт товару $i$ з країн $j$ та $h$ до країни $k$;

$D_{j k}$ и $D_{h k}-$ відстань між країнами $j$ та $k \breve{~ и ~}$ країнами $h$ та $k$ відповідно;
$X R$ - середня річна динаміка обмінного курсу національних валют країн $j$ та $k$ відповідно до долару США за період з 2012 до 2015 р. включно;

$T$ - дія нетарифнного захисту, що виражається у затримках поставок товарів на кордоні (в годинах) при митних перевірках;

$D$ - набір фріктивних змінних, що включають наявність або відсутність спільного кордону, історичні відносини «метрополія - колонія», спільну мову, наявність або відсутність виходу до моря.

Таблиця 2

\begin{tabular}{|c|c|c|c|}
\hline $\begin{array}{c}\text { Метод оцінки } \\
\text { впливу }\end{array}$ & Загальна схема & Переваги & Недоліки \\
\hline $\begin{array}{c}\text { Частотний } \\
\text { аналіз }\end{array}$ & $\begin{array}{c}\text { Розрахунок частки } \\
\text { товарних позицій або } \\
\text { обсягу імпорту щодо яких } \\
\text { застосовуються нетарифні } \\
\text { заходи }\end{array}$ & $\begin{array}{c}\text { Простота розрахунку. } \\
\text { Мінімум необхідних } \\
\text { даних для розрахунку }\end{array}$ & $\begin{array}{c}\text { Дозволяє визначити } \\
\text { поширеність } \\
\text { нетарисрних заходів, } \\
\text { тоді як для оцінки } \\
\text { їхнього впливу на } \\
\text { торговельні потоки або } \\
\text { межчасовий порівнянь } \\
\text { не підходить } \\
\end{array}$ \\
\hline $\begin{array}{c}\text { Оцінка різниці } \\
\text { цін }\end{array}$ & $\begin{array}{c}\text { Оцінка різниці ціни } \\
\text { імпортованого товару } \\
\text { на внутрішньому } \\
\text { ринку з ціною цього ж } \\
\text { товару у зарубіжного } \\
\text { постачальника }\end{array}$ & \begin{tabular}{|c|} 
Дозволяє розраховувати \\
показник впливу \\
нетарифних заходів \\
на ціноутворення \\
імпортних товарів - \\
тарифний еквівалент \\
нетарифрних заходів \\
\end{tabular} & $\begin{array}{c}\text { Необхідні надійні дані } \\
\text { за цінами імпортованих } \\
\text { товарів на різних } \\
\text { стадіях поставки. } \\
\text { Складно врахувати інші } \\
\text { фактори ціноутворення }\end{array}$ \\
\hline $\begin{array}{c}\text { Розрахунок } \\
\text { змін цін } \\
\text { внаслідок } \\
\text { кількісних змін } \\
\text { обсягу імпорту }\end{array}$ & \begin{tabular}{|c} 
Оцінка впливу нетарифних \\
заходів на основі різниці \\
обсягів імпорту до і після \\
введення нетарифних \\
заходів й еластичності \\
попиту на імпортний товар \\
на внутрішньому ринку \\
\end{tabular} & $\begin{array}{c}\text { Вимагає даних щодо } \\
\text { обсягів імпорту, а не } \\
\text { за цінами імпортних } \\
\text { товарів }\end{array}$ & $\begin{array}{c}\text { Необхідна оцінка } \\
\text { еластичності попиту } \\
\text { по кожному товару, } \\
\text { що розглядається }\end{array}$ \\
\hline $\begin{array}{c}\text { Індексний } \\
\text { аналіз } \\
\text { опитувальних } \\
\text { даних }\end{array}$ & $\begin{array}{c}\text { Бальна оцінка } \\
\text { опитуваними учасниками } \\
\text { зовнішньоекономічної } \\
\text { діяльності впливу } \\
\text { нетарифрних заходів }\end{array}$ & $\begin{array}{c}\text { Простота застосування } \\
\text { (немає необхідності } \\
\text { в даних за цінами, } \\
\text { обсягами або } \\
\text { еластичністю } \\
\text { імпортованих товарів) }\end{array}$ & $\begin{array}{c}\text { Суб'єктивність оцінок. } \\
\text { Недостатня точність } \\
\text { при інтервальних } \\
\text { оцінках. Висока } \\
\text { трудомісткість } \\
\text { опитувань } \\
\end{array}$ \\
\hline $\begin{array}{c}\text { Економетричні } \\
\text { оцінки }\end{array}$ & $\begin{array}{c}\text { Розрахунок змін під } \\
\text { впливом нетарифнних } \\
\text { заходів }\end{array}$ & $\begin{array}{c}\text { Залежно від } \\
\text { специфікації моделі } \\
\text { дозволяє розраховувати } \\
\text { як зміну обсягів імпорту/ } \\
\text { експорту, так і тарифрні } \\
\text { еквіваленти нетарифних } \\
\text { заходів. Дозволяє } \\
\text { враховувати й оцінювати } \\
\text { інші чинники зовнішньої } \\
\text { торгівлі (відстань, обсяги } \\
\text { економік, митні збори, } \\
\text { спільний кордон тощо) } \\
\end{array}$ & $\begin{array}{c}\text { Складність } \\
\text { специфікацій } \\
\text { і розрахунків } \\
\text { економетричних } \\
\text { моделей. } \\
\text { Ендогенність. } \\
\text { Волатильність за } \\
\text { специорікацією моделі } \\
\text { (різні результати } \\
\text { при різних наборах } \\
\text { пояснюючих змінних) }\end{array}$ \\
\hline
\end{tabular}

Характеристика основних підходів до оцінки впливу заходів нетарифного регулювання на показники міжнародної торгівлі 
Отримані в ході розрахунків результати показали можливе зниження взаємної торгівлі на 9,6\%. При цьому всі перераховані методи мають як сильні, так і слабкі сторони, пов'язані з доступністю даних, механізмами розрахунків і оцінок, надійністю і релевантністю отриманих результатів (табл. 2).

Висновки. Таким чином, основні методичні підходи до оцінки впливу нетарифнних заходів на показники міжнародної торгівлі, що були проаналізовані, забезпечують в тій чи іншій мірі оцінку рівня та інтенсивності застосування цих заходів для експортерів, чи то показники поширеності заходів нетарифного регулювання (частотний метод), зміни цін, обсягів імпорту, чи то тарифні еквіваленти (методи різниці цін і економетричні моделі).

Разом з тим характерні для кожного з розглянутих методів переваги й недоліки обумовлюють необхідність вибору відповідної методики в залежності від цілей дослідження і наявних даних.

\section{СПИСОК ВИКОРИСТАНИХ ДЖЕРЕЛ:}

1. Balassa B., Balassa C. Industrial Protection in the Developed Countries. The World Economy. 1984. Vol. 7. No. 2 P. 179-196. URL: https://onlinelibrary.wiley.com/doi/abs/10.1111/j.1467-9701.1984.tb00268.x

2. Baldwin R. E. Non-tariff Distortions of International Trade. The Economic Journal. 1972. Vol. 82. No. 325. P. 265-266. DOI: https://doi.org/10.2307/2230243

3. Ball R. J., Linnemann H. An Econometric Study of International Trade Flows. The Economic Journal. 1967. Vol. 77. No. 306. P. 366-368. DOI: https://doi.org/10.2307/2229319

4. Basu S.R., Kuwahara H., Dumesnil F. Evolution of Non-Tariff Measures: Emerging Cases from Selected Developing Countries. Policy Issues in International Trade and Commodities, 2012. Study Series. No. 52. New York and Geneva. URL: https://digitallibrary.un.org/record/743678

5. Berden K. G., Francois J., Thelle M., Wymenga P., Tamminen S. NonTariff Measures in EU-US Trade and Investment: an Economic Analisys: Final Report for the European Commission. Rotterdam, ECORYS Nederland BV. 2009. URL: https://www.gtap.agecon.purdue.edu/resources/download/5177.pdf

6. Bergstrand Jeffrey $\mathrm{H}$. The Gravity Equation in International Trade: Some Microeconomic Foundations and Empirical Evidence. The Review of Economics and Statistics. 1985. Vol. 67. No. 3. P. 474-81. DOI: https://doi.org/ $10.2307 / 1925976$

7. Bhagwati Jagdish N., Srinivasan T. N.. Revenue Seeking: A Generalization of the Theory of Tariffs. Journal of Political Economy. 1980. Vol. 88. No. 6. P. 1069-87. URL: http://www.jstor.org/stable/1831156

8. Byrne S., Rice J. Non-Tariff Barriers and Goods Trade: a Brexit Impact Analysis, Research Technical Papers. 2018. No. 6. Central Bank of Ireland. URL: https://www.centralbank.ie/docs/default-source/publications/researchtechnical-papers/06rt18-non-tarriff-barriers-and-goods-trade-a-brexit-impact-analysis-(byrne-and-rice).pdf? sfvrsn=4

9. Dean J. M., Signoret J. E., Feinberg R. M., Ludema R. D., Ferrantino M. J. Estimating the Price Effects of Non-Tariff Barriers. The B.E. Journal of Economic Analysis \& Policy. De Gruyter. 2009. Vol. 9(1). P. 1-41. URL: https://www.usitc.gov/publications/332/EC200606Ar.pdf

10. DeardorffA., Stern R. Measurement of Non-Tariff Barriers. OECD Economics Department Working Papers. 1997. No. 179. ECD Publishing, Paris. URL: https://econpapers.repec.org/scripts/showcites.pf?h=repec:oec:ecoaaa:179-en

11. El-Agraa Ali M., Jones Anthony J. Macroeconomics of Regional Integration: Withdrawal from a Customs Union. Journal of Economic Integration 2008. Vol. 23. No. 1. P. 75-90. URL: http://www.jstor.org/stable/23001112

12. Ferrantino M. Quantifying the Trade and Economic Effects of Non-Tariff Measures. OECD Trade Policy Papers, No. 28 (2006). OECD Publishing, Paris. DOI: http://dx.doi.org/10.1787/837654407568

13. Gourdon J. CEPII NTM-MAP: a Tool for Assessing the Economic Impact of Non-Tariff Measures. CEPII Working Paper. 2014. December. URL: http://www.cepii.fr/pdf_pub/wp/2014/wp2014-24.pdf

14. Hoekman B., Nicita A. Trade Policy, Trade Costs, and Developing Country Trade. World Development. 2011. Vol. 12. No. 39. P. 2069-79. URL: https://econpapers.repec.org/article/eeewdevel/v_3a39_3ay_3a2011_3ai_3a12_ 3ap_3a2069-2079.htm

15. Hummels David L., Schaur Georg. Time as a Trade Barrier. American Economic Review. 2013. Vol. 103(7). P. 2935-59. DOI: https://doi.org/10.1257/aer.103.7.2935

16. Kepaptsoglou K., Karlaftis M. G., Tsamboulas D. The Gravity Model Specification for Modeling International Trade Flows and Free Trade Agreement Effects: a 10-year Review of Empirical Studies. The Open Economics Journal. 2010. Vol. 3. P. 1-13. DOI: http://dx.doi.org/10.2174/1874919401003010001

17. Morici P. U.S. Economic Policies Affecting Industrial Trade: a Quantitative Assessment. Washington, D.C., National Planning Association, 1983. 
18. Moroz A. R. Approaches and Methodologies for Estimating NonTariff Barriers. Ottawa, 1985.

19. Moroz A. R., Brown S. L. Grant Support and Trade Protection for Canadian Industries. Ottawa, Government of Canada, 1987.

20. Nogues J. J., Olechowski A., Winters L. A. The Extent of Nontariff Barriers to Imports of Industrial Countries, The World Bank Staff Working Paper. 1986. No. SWP 789. URL: https://econpapers.repec.org/article/oupwbecrv/ v_3a1_3ay_3a1986_3ai_3a1_3ap_3a181-99.htm

21. Non-Tariff Measures: Evidence from Selected Developing Countries and Future Research Agenda. United Nations Conference on Trade and Development. New York; Geneva, 2010. URL: https://digitallibrary.un.org/ record/697870?!n

22. Obstfeld M., Rogoff K. The Six Major Puzzles in International Macroeconomics: is there a Common Cause? NBER Macroeconomics Annual. 2000. Vol. 1(15). P. 339-390. URL: https://www.nber.org/papers/w7777

23. Rodriguez C. A. The Non-Equivalence of Tariffs and Quotas under Retaliation, Journal of International Economics. Elsevier. 1974. Vol. 4(3). P. 295-298. URL: https://ideas.repec.org/a/eee/inecon/v4y1974i3p295-298.html

24. Staiger R.W. Non-Tariff Measures and the WTO. Dartmouth and NBER. 2015. URL: https://www.wto.org/ english/res_e/reser_e/ersd201201_e.pdf

25. Studies on Regulatory and Procedural Barriers to Trade. UNECE. URL: https://unece.org/trade/studiesregulatory-and-procedural-barriers-trade

26. Tucci A., Loridan M. Navigating Non-Tariff Measures: Insights from a Business Survey in the European Union. Geneva. ITC/EC. 2016. URL: https://trade.ec.europa.eu/doclib/docs/2016/december/tradoc_155181.pdf

27. World Tariff Profiles 2016. Geneva. ITC. UNCTAD. 2016. URL: https://unctad.org/system/files/officialdocument/wto2016_en.pdf

28. World Trade Report 2012. Geneva, 2012. URL: https://www.wto.org/english/res_e/booksp_e/anrep_e/world_ trade_report12_e.pdf

\section{REFERENCES:}

1. Balassa, B., Balassa, C. (1984) Industrial Protection in the Developed Countries. The World Economy, vol. 7 , no. 2, 179-196. Available at: https://onlinelibrary.wiley.com/doi/abs/10.1111/j.1467-9701.1984.tb00268.x

2. Baldwin, R. E. (1972) Non-tariff Distortions of International Trade. The Economic Journal, vol. 82, no. 325, 265-266. DOI: https://doi.org/10.2307/2230243

3. Ball, R. J., Linnemann, H. (1967) An Econometric Study of International Trade Flows. The Economic Journal, 77, no. 306, 366-368. DOI: https://doi.org/10.2307/2229319

4. Basu, S.R., Kuwahara, H., Dumesnil, F. (2012) Evolution of Non-Tariff Measures: Emerging Cases from Selected Developing Countries. Policy Issues in International Trade and Commodities. Study Series, no. 52. New York and Geneva. Available at: https://digitallibrary.un.org/record/743678

5. Berden, K. G., Francois, J., Thelle, M., Wymenga, P., Tamminen, S. (2009) NonTariff Measures in EU-US Trade and Investment: an Economic Analisys: Final Report for the European Commission. Rotterdam, ECORYS Nederland BV. Available at: https://www.gtap.agecon.purdue.edu/resources/download/5177.pdf

6. Bergstrand, Jeffrey H. (1985) The Gravity Equation in International Trade: Some Microeconomic Foundations and Empirical Evidence. The Review of Economics and Statistics, 67, no. 3, 474-81. DOI: https://doi.org/ $10.2307 / 1925976$

7. Bhagwati, Jagdish N., and T. N. Srinivasan (1980) Revenue Seeking: A Generalization of the Theory of Tariffs. Journal of Political Economy, 88, no. 6, 1069-87. Available at: http://www.jstor.org/stable/1831156

8. Byrne, S., Rice, J. (2018) Non-Tariff Barriers and Goods Trade: a Brexit Impact Analysis, Research Technical Papers, no. 6. Central Bank of Ireland. Available at: https://www.centralbank.ie/docs/default-source/publications/researchtechnical-papers/06rt18-non-tarriff-barriers-and-goods-trade-a-brexit-impact-analysis-(byrne-and-rice).pdf?sfvrsn=4

9. Dean, J. M., Signoret, J. E., Feinberg, R. M., Ludema, R. D., Ferrantino, M. J. (2009) Estimating the Price Effects of Non-Tariff Barriers. The B.E. Journal of Economic Analysis \& Policy, 1, De Gruyter, vol. 9, 1-41. Available at: https://www.usitc.gov/publications/332/EC200606Ar.pdf

10. Deardorff, A., Stern, R. (1997) Measurement of Non-Tariff Barriers. OECD Economics Department Working Papers, no. 179. ECD Publishing, Paris. Available at: https://econpapers.repec.org/scripts/showcites. pf?h=repec:oec:ecoaaa:179-en

11. El-Agraa, Ali M., and Anthony J. Jones (2008) Macroeconomics of Regional Integration: Withdrawal from a Customs Union. Journal of Economic Integration, 23, no. 1, 75-90. Available at: http://www.jstor.org/stable/23001112

12. Ferrantino, M. (2006) Quantifying the Trade and Economic Effects of Non-Tariff Measures, OECD Trade Policy Papers, no. 28. OECD Publishing, Paris. Available at: http://dx.doi.org/10.1787/837654407568 
13. Gourdon J. (2014) CEPII NTM-MAP: a Tool for Assessing the Economic Impact of Non-Tariff Measures, CEPII Working Paper, December. Available at: http://www.cepii.fr/pdf_pub/wp/2014/wp2014-24.pdf

14. Hoekman, B., Nicita, A. (2011) Trade Policy, Trade Costs, and Developing Country Trade". World Development 12, no. 39, 2069-79. Available at: https://econpapers.repec.org/article/eeewdevel/v_3a39_3ay_3a2011_3ai_ 3a12 3ap 3a2069-2079.htm

15. Hummels, David L., and Georg Schaur (2013) Time as a Trade Barrier." American Economic Review, 103(7), 2935-59. DOI: https://doi.org/10.1257/aer.103.7.2935

16. Kepaptsoglou, K., Karlaftis, M. G., Tsamboulas, D. (2010) The Gravity Model Specification for Modeling International Trade Flows and Free Trade Agreement Effects: a 10-year Review of Empirical Studies. The Open Economics Journal, vol. 3, 1-13. DOI: http://dx.doi.org/10.2174/1874919401003010001

17. Morici P. (1983) U.S. Economic Policies Affecting Industrial Trade: a Quantitative Assessment. Washington, D.C.: National Planning Association.

18. Moroz, A. R. (1985) Approaches and Methodologies for Estimating NonTariff Barriers. Ottawa.

19. Moroz, A. R., Brown, S. L. (1987) Grant Support and Trade Protection for Canadian Industries. Ottawa, Government of Canada.

20. Nogues, J. J., Olechowski, A., Winters, L. A. (1986) The Extent of Nontariff Barriers to Imports of Industrial Countries, The World Bank Staff Working Paper, no. SWP 789. Available at: https://econpapers.repec.org/article/ oupwbecrv/v_3a1_3ay_3a1986_3ai_3a1_3ap_3a181-99.htm

21. Non-Tariff Measures: Evidence from Selected Developing Countries and Future Research Agenda (2010) United Nations Conference on Trade and Development. New York; Geneva. Available at: https://digitallibrary.un.org/ record/697870?!n

22. Obstfeld, M., Rogoff, K. (2000) The Six Major Puzzles in International Macroeconomics: is there a Common Cause? NBER Macroeconomics Annual, 15, vol. 1, 339-390. Available at: https://www.nber.org/papers/w7777

23. Rodriguez, C. A. (1974) The Non-Equivalence of Tariffs and Quotas under Retaliation. Journal of International Economics, 3, Elsevier, vol. 4, 295-298. Available at: https://ideas.repec.org/a/eee/inecon/v4y1974i3p295-298.html

24. Staiger, R.W. (2015) Non-Tariff Measures and the WTO. Dartmouth and NBER. Available at: https://www.wto.org/english/res_e/reser_e/ersd201201_e.pdf

25. Studies on Regulatory and Procedural Barriers to Trade. UNECE. Available at: https://unece.org/trade/ studies-regulatory-and-procedural-barriers-trade

26. Tucci, A., Loridan, M. (2016) Navigating Non-Tariff Measures: Insights from a Business Survey in the European Union. Geneva, ITC/EC. Available at: https://trade.ec.europa.eu/doclib/docs/2016/december/tradoc_155181.pdf

27. World Tariff Profiles 2016. Geneva, ITC, UNCTAD (2016). Available at: https://unctad.org/system/files/ official-document/wto2016_en.pdf

28. World Trade Report 2012 (2012). Geneva. Available at: https://www.wto.org/english/res_e/booksp_el anrep_e/world_trade_report12_e.pdf 